\title{
EXPLORING FACTORS INFLUENCING ELECTRIC VEHICLE USAGE INTENTION: AN EMPIRICAL STUDY IN MALAYSIA
}

\author{
Yew-Ngin Sang* \\ Universiti Tenaga Nasional \\ Hussain Ali Bekhet \\ Universiti Tenaga Nasional
}

\begin{abstract}
The rationale of this study is to investigate the factors influencing electric vehicle usage intention in Malaysia. Empirical study using survey questionnaires are distributed to a judgment sampling of 500 drivers in Selangor and Federal Territories (Kuala Lumpur and Putrajaya). A research model based on the Theory of Planned Behavior was proposed as the underlying framework to realize the objective of the study. Linear regression-stepwise technique was used to test the research hypotheses. The results finding indicated that the electric vehicle usage intention in Malaysia is very much influenced by Environmental Concern, Consumer Knowledge, Psychological Benefits and Demographics. Hence, this paper provides valuable information for automotive players planning to market electric vehicles in Malaysia. It offers insights for formulation of marketing strategies that will address the real wants and needs of their future clients based on the identified factors in this study. Meanwhile, policy makers should formulate appropriate intervention and policies to encourage the growth of electric vehicles usage in Malaysia as a strategy to increase energy efficiency, reduce carbon emissions and minimize the reliance on fossil fuel in the automotive sector. Future study is suggested to be done to explore more factors that might influence public acceptance and to improve characterization of respondents by including more cities in Malaysia.
\end{abstract}

Keywords: Public Acceptance; Usage Intention; Electric Vehicles; Malaysia.

\section{INTRODUCTION}

The increase in economic status and consumer purchasing power worldwide has raised the world population mobility and this has resulted in a significant increase in carbon emissions particularly from the transportation sector. Rising incomes are always associated with higher levels of car ownership and usage (Webster, Bly, Johnson and Dasgupta, 1986a; 1986b) and greater travel frequency and distances (Schafer, 2000). In most of the Asian countries, the

\footnotetext{
- Corresponding author: Graduate Business School, College of Graduate Studies, Universiti Tenaga Nasional (UNITEN), Putrajaya Campus, Jalan IKRAM-UNITEN, 43000 Kajang, Selangor Darul Ehsan, Malaysia. E-mail: eugenesyn@hotmail.com Tel:+6019-8885122
} 
transport sector already accounts for a substantial share of total national carbon emissions. Therefore, due consideration should be given to the transport sector in any attempt to deal with emissions reduction.

In Malaysia, the energy demand for transportation sector has risen steeply between 1990 and 2012. The average growth rate was recorded at $5.7 \%$ and accounted for about $39 \%$ of the final energy consumption in the country (Energy Commission, 2014) with the average growth rate of newly registered private vehicles stood at 8.7\% (Road Transport Department, 2013). In term of carbon emission, transportation sector continued to be one of the largest contributors due to a large portion of its energy supply were still derived from fossil fuels (Lim and Lee, 2012). In addition, it was reported that energy efficiencies of the road transportation in Malaysia were only $18.88 \%$ (Saidur, Sattar, Masjuki, Ahmed and Hashim, 2007). It was reported that only $12.6 \%$ of the total energy is used as useful exertion in the study on automobile internal combustion (Mahlia, Tohno and Tezuka, 2012). This situation was further worsening by the inefficiency of the public transportation which has resulted in heavy dependence on passenger vehicles.

Therefore, it is a priority for the government to formulate effective strategies for greening the transportation sector as one of the main agenda towards sustainable and green economy development. Electrification is viewed as the key and important answer to cut carbon emission and increase energy efficiency within the transportation sector. Works on strategy and roadmap such as the National Green Technology Policy and Electric Vehicles Infrastructure Roadmap has identified several promising initiatives that could facilitate emissions reduction and efficient use of energy. The remaining question is how the way forward may be unfold and how it can be governed. A comprehensive and systemic policy strategy for technology development and deployment is required to overcome the numerous hurdles for radical future technologies in the transportation sector and manage the public acceptance.

Electric vehicle is set to be promoted to the mass market in Malaysia as one of the solutions to reduce fossil fuel dependency and carbon emission generated from the transportation sectors particularly in the personal transportation segment. There is growing agreement that electric vehicle is a viable sustainable strategy to 'decarbonizes' personal transportation as it improve air quality and the 'near to market' green technology (Mayor of London, 2009; Shen, Han, Chock, Chai and Zhang, 2012). Nevertheless, besides the supply push for electric vehicles into Malaysian market, it also requires public acceptance to make it viable. Driven by the desire to promote and encourage the usage of electric vehicle in Malaysia, the researchers intend to investigate and find out the factors influencing usage intention of electric vehicle through this study.

Specifically, this study will be based on the Theory of Planned Behavior (TPB) as the underlying framework to explore the effects of environmental concern, consumer knowledge, psychological benefit, infrastructure readiness and demographics on usage intention. In order to develop a research model for the current study, a literature review relating to TPB and factors that may influence the usage intention of electric vehicle were undertaken. This will be followed by hypotheses development and research methodology. Subsequently results are presented, discussed and directions for further research are suggested. 


\section{THEORY BACKGROUND AND THEORETICAL REVIEW}

The Theory of Planned Behavior is a commonly employed framework to explicate human behaviors. The TPB distinguishes between three types of beliefs - behavioral, normative and control between the related constructs of attitudes, subjective norm and perceived behavioral control (Ajzen, 1991). In combination, attitude, subjective norm and perceived behavioral control lead to the formation of behavioral intention. Behavior is decided by an individual's intention which captures the motivation to engage in the behavior (Azjen, 1991). Individuals with stronger intention to engage in a particular behavior are more probable to execute that behavior and therefore, intention is often used as a proxy of future behavior (Sheppard, Hartwick and Warshaw, 1988). Within the transportation research literatures, TPB has been extensively utilized as the underlying framework to predict various behaviors such as speeding intention (Cristea, Paran and Delhomme, 2013; Horvath, Lewis and Watson, 2012), travel mode choice (Chen and Chao, 2011; Hsiao and Yang, 2010), drink and drive behavior (Moan, 2013; Rivis, Abraham and Snook, 2011) and seat belt usage (Okamura, Fujita, Kihira, Kosuge and Mitsui, 2012). Although the TPB is regarded as a complete theory of behavior, it permits for the inclusion of additional variables, provided these variables make a noteworthy input to the explanation of behavior provided by the model (Azjen, 1991). In order to capture the theory's richness, we expand the intention paradigm by considering variables that are not previously examined. Therefore, we have incorporated variables such as environmental concern, consumer knowledge, psychological benefits, infrastructure readiness and demographics to be investigated in this study.

\subsection{Environmental Concern (EC)}

For the purpose of this study, environmental concern was defined as the degree to which people are aware of problems regarding the environment and support the effort to solve them or indicate the willingness to contribute personally to the solution. Sensitivity to climate-change issues, awareness of clean energy and energy conservation constitute explicit dimensions of environmental concern (Simsekoglu and Lajunen, 2008). As there is a general increase in environmental concern across the population, Roberts (1996) strongly suggests that this important relationship to be further investigated. Environmental concern was suggested being more influential for some behavior than others (Roberts and Bacon, 1997; Schahn and Holzer, 1990). Several previous studies have confirmed that consumer's environmental concern influences purchase behavior of environmentally safe products (Roberts and Bacon, 1997; Balderjahn, 1988; Ellen, Wiener and Cobb-Walgren, 1991; Martin and Simintiras, 1995). There is also support of environmental concern's direct and indirect effects on consumer willingness to procure green product at premium price (Bang, Ellinger, Hadjimarcou and Traichal, 2000; Hansla, Gamble, Juliusson and Garling, 2008; Laroche, Bergeron and Barbara-Forleo, 2001). In addition, prior studies on new vehicle technologies have attempted to recognize how environmental benefits may affect customer decisions (Ewing and Sarigollu, 1998; Gould and Golob, 1998; Schuitema, Anable, Skippon and Kinnear, 2013).Therefore, it is hypothesized that:

H1: There is statistical significant relationship and impact between Environmental Concern (EC) and Usage Intention (INT). 


\subsection{Consumer Knowledge (CK)}

In the context of this study, consumer knowledge was defined as familiarity with facts, information, descriptions, or skills acquired through experience or education and can be referred to the theoretical or practical understanding of a subject. Ellen (1994) has suggested that consumer education is important in encouraging decision making in the consumer marketplace. Consumer knowledge has shown to be able to predict behavior in adopting or using a product (Ellen, 1994; Lyons and Breakwell, 1994). Furthermore, Scott (1997) observed that knowledge about potential energy savings is associated with higher take-up of energy efficient technologies. Since electric vehicle is widely acknowledged as an energy efficient product, consumer knowledge about this product will definitely influence the decision towards adopting electric vehicles. Adoption is also influenced by the perception and awareness about the attributes of the new technologies (Lane and Potter, 2007). Consumers are found to be using existing knowledge to learn about innovative products or services (Gregan-Paxton and John, 1997). In a study carried out by Mourato, Saynor and Hart (2004) on driver's preferences for fuel cell taxis in London, it was found that drivers who were more familiar with the technology are willing to pay more to use the technology. In term of energy-efficient technologies, Mills and Schleich (2012) suggested that information on energy consumption, conservation opportunities and the energy performance of technologies is expected to affect the adoption. In the previous study carried by Thesen and Langhelle (2008) and O'Garra, Mourato and Pearson (2005), it was concluded that knowledge was an important determinant of support for wider application in transportation. Research in psychology and marketing disciplines has also documented that consumers' knowledge has a significant effect on their decision-making (Saaksjarvi, 2003). Therefore, it is hypothesized that:

H2: There is statistical significant relationship and impact between Consumer Knowledge (CK) and Usage Intention (INT).

\subsection{Psychological Benefit (PB)}

Psychological benefits would be identified as a reward or benefits arises compared to usual alternatives and 'feeling better' which enhance status and reputation arises by choosing a certain product. Consumers perceived that the consumption of products with environmentally sound attributes delivers further benefits compared to usual alternatives (Bech-Larsen, 1996; Sriram and Forman, 1993). Decoupling global warming and energy dependency will becomes a collective benefit when widespread adoption occurs while green branding offers psychological benefits to the consumers (Hartmann and Apaolaza-Ibanez, 2012). They have also suggested that consumers may conspicuously consume environmentally-friendly products in order to display pro-environmental attitudes to enhance status and reputation and willing to incur extra cost for the sake of the environment and society. Previous empirical findings suggested that some consumers were willing to purchase green product at a premium price in order to feel better themselves and demonstrated a status motives rather than the impact on environment (Wustenhagen and Bilharz, 2006; Griskevicius, Tybur and van den Bergh, 2010). Additional consumer benefits are important and were known to be the key factor for demand of green products (Kammerer, 2009). Psychological benefit expectations from purchasing green product 
should enhance consumer's attitude towards purchase intention and adoption. Therefore, the researchers believe psychological benefits play an important role in electric vehicle acceptance and concluded that:

H3: There is statistical significant relationship and impact between Psychological Benefit (PB) and Usage Intention (INT).

\subsection{Infrastructure Readiness (IR)}

In this study, Infrastructure Readiness refers to the availability of public charging station (technology facilitating conditions) to the consumers to recharge their electric vehicles. Sperling and Kitamura (1986) suggested that the key reason impeding the introduction of new transportation fuel is due to unavailability of retail infrastructure selling those fuels. This is important particularly during decision making process of whether or not to buy a vehicle running on new fuel type. Accessibility to electric grid used for charging besides efficiency and emissions, is one of the important factors impacting the magnitude of plug-in hybrid electric vehicles (Skerlos and Winebrake, 2010). Previous studies have shown that the lack of charging infrastructure is one of the reasons on why electric vehicles have not been widely accepted, despite the low environmental impact and high energy efficiency (Anegawa, 2010; Martin, Shaheen, Lipman and Lidicker, 2009). Besides that, limited driving range and longer recharging time are also among the setbacks toward electric vehicle adoption among the consumers (Garling and Thorgersen, 2001; Ustaoğluand Yildiz, 2012). It was suggested that fast-charging infrastructure will benefit and facilitate long-range drives for electric vehicles and this may be crucial to push forward the market penetration of electric vehicles (Schroeder and Traber, 2012). This is very much supported by Liu (2012) who suggested that the spatial distributions are both largely determined by charging demands / local refueling even though the fact that there are many differences between electric vehicle charging infrastructure and petrol refueling station. On the other hand, findings by Dagsvik, Wennemo, Wetterwald and Aaberge, 2002) implied that alternative fuel vehicles appeared to be competitive with conventional vehicles provided the refueling infrastructure is in place. For that reason, infrastructure readiness plays an important role in order to increase the market penetration and public acceptance. Therefore, it is hypothesized that:

H4: There is statistical significant relationship and impact between Infrastructure Readiness (IR) and Usage Intention (INT).

\subsection{Demographics $(D G)$}

Many researchers have suggested that demographic characteristics affect the usage intention of a product. Age, gender, education, income and family size have been found to be significantly correlated with environmental behavior (Roberts, 1996; Roberts and Bacon, 1997; Martinsons, So, Tin and Wong, 1997). Study by Newell and Green (1997) shown positive relationships between income and environmental behaviors. This is because individuals with higher income level can bear the marginal increase in cost associated with favoring green products. In term of preferences for alternative fuel vehicles, it was revealed that college-educated respondents preferred electric vehicles (Brownstone, Bunch and Train, 2000) while as for 
green consumption, women was reported significantly more participative as compared to men (Mainieri, Barnett, Valdero, Unipan and Oskamp, 1997). Segmentation variables i.e. gender, age and education level were very much significant in preferences towards adoption of cleaner vehicles (Potogluo and Kanaroglou, 2007). In the case of Malaysian consumers, Bekhet and Al-allak $(2011,2014)$ found a significant relationship between demographics characteristics and intention in their study on the use of e-statement. Therefore, it is hypothesized that:

H5: There is statistical significant relationship and impact between Demographic (DG) and Usage Intention (INT).

\section{PROPOSED ELECTRIC VEHICLE ACCEPTANCE MODEL}

This proposed Electric Vehicle Acceptance Model is a rather modified and revised model that addresses the peculiarities of electric vehicles as a 'green' product. Furthermore, as the purpose of the current study is to investigate the key predictors that have direct impact on the electric vehicle usage intention, relevant and essential factors are added to the proposed adoption model. As such, five factors are identified, namely; environmental concern, consumer knowledge, psychological benefits, infrastructure readiness and demographic (refer Figure 1).

Figure 1: Electric Vehicle Acceptance Model

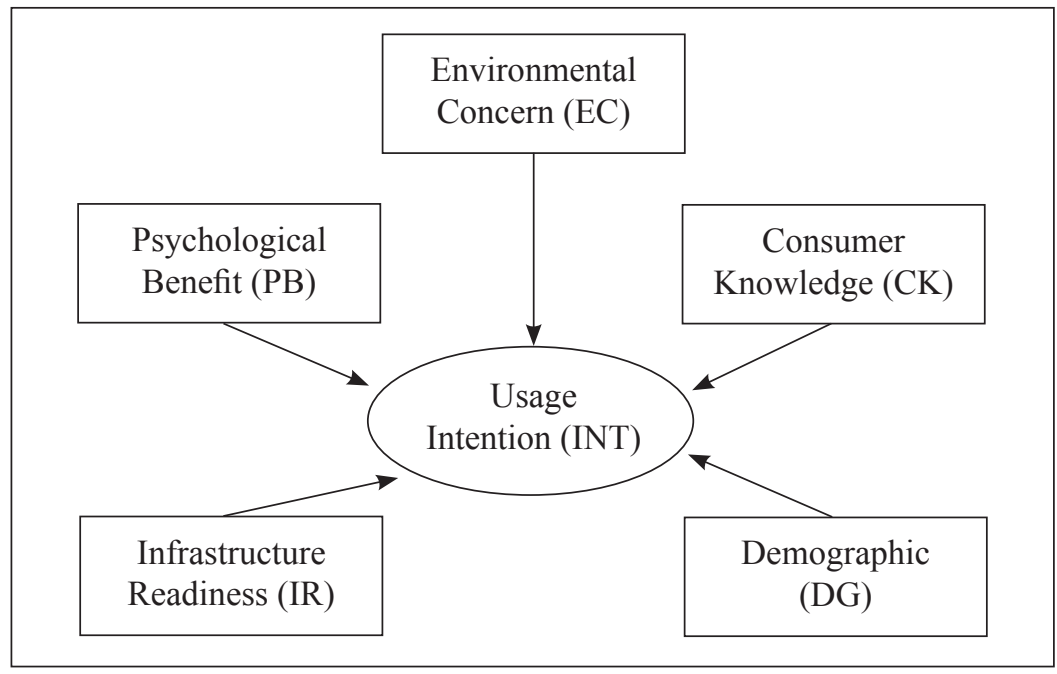

\section{DATA SOURCES AND METHODOLOGY}

A survey research was designed and implemented to collect empirical data with respect to the factors that influence the intention to use electric vehicles in Malaysia. The required primary data was obtained through a self-administered questionnaire using multiple items on a 5-point Likert-type scale that range from $1=$ strongly disagree to $5=$ strongly agree. A total 
of 500 questionnaires were distributed to Malaysian drivers to participate in this study. In order to ensure their perceptions are based on familiarity and experience of driving vehicles, the questionnaire was given only to respondents with prior vehicle driving experience and possessed a valid private vehicle driving license. The questionnaire consisted of two sections. Section one covered questions on demographic characteristics and section two focused on the factors influencing the intention to use electric vehicles. Majority of the respondents were drawn within Selangor and Federal Territories (Kuala Lumpur and Putrajaya). The justification of choosing these states is purely based on the Gross Domestic Product (GDP) contribution. Selangor and Federal Territories (Kuala Lumpur and Putrajaya) are the top contributors (38\%) in term of the overall national GDP input. SPSS (version 21) were employed for the analysis. As for the analysis techniques, Descriptive Analysis, Reliability Test, Intercorrelation and Linear Regression-Stepwise were used to test the hypotheses and to achieve the objective of this study.

\section{RESULT ANALYSIS AND DISCUSSION}

\subsection{Respondent Profile}

From the 500 questionnaires distributed, 346 completed questionnaires were received and analyzed in this study. The response rate was $69.2 \%$ (see Table 1 ). In term of gender perspective, the distributions between male and female respondents were fairly balance i.e. $54 \%$ male and $46 \%$ female. In this survey, the Chinese represent about $50 \%$, followed by $39.5 \%$ Malay, $8.5 \%$ Indian and other races representation of $2 \%$ of the total respondents. Majority of the respondents were well educated with $70 \%$ of them were university graduates and postgraduate, within the age group of 29-50 years old and married. In term of income, $65 \%$ of the respondents were within the RM3,000 - RM9,000 per month. As for the vehicle driving experience, respondents with more than 16 years of experience achieved the highest percentage i.e. at $39 \%$ followed by $26 \%$ within $11-16$ years of driving experience.

\subsection{Reliability and Descriptive Analysis}

For the descriptive analysis, the mean value was within 2.96-3.82, standard deviation within $0.59-0.82$ and skewness within -0.699 to +0.054 (see Table 2 ) suggesting good normality of the factors investigated. Reliability was assessed by measuring Cronbach's $\alpha$ coefficient to check the internal consistency among items. Ideally the Cronbach's $\alpha$ values of a scale should be above 0.70 (Pallant, 2011). In the current study, the Cronbach's $\alpha$ for overall scale of each factor was within $0.70-0.87$ suggesting a very strong consistency among the items for each factor (see Table 2). We also measured the inter-item correlation as the number of items in the scale is less than ten items. In order to suggest a strong correlation, Briggs and Cheek (1986) proposed the range should be within 0.2-0.6. In the current study, the inter-item correlation was found to be within $0.285-0.573$ which suggested a strong relationship among the items. 
Table 1: Demographic attributes of the respondents $(n=346)$

\begin{tabular}{|c|c|c|}
\hline Respondents' profile & Frequency & Percentage $(\%)$ \\
\hline \multicolumn{3}{|l|}{ Gender } \\
\hline Male & 187 & 54.0 \\
\hline Female & 159 & 46.0 \\
\hline \multicolumn{3}{|l|}{ Ethnic Group } \\
\hline Malay & 136 & 39.3 \\
\hline Chinese & 174 & 50.3 \\
\hline Indian & 29 & 8.4 \\
\hline Others & 7 & 2.0 \\
\hline \multicolumn{3}{|l|}{ Age Group } \\
\hline $18-28$ & 56 & 16.2 \\
\hline $29-39$ & 175 & 50.6 \\
\hline $40-50$ & 70 & 20.2 \\
\hline $51-61$ & 39 & 11.3 \\
\hline$>61$ & 6 & 1.7 \\
\hline \multicolumn{3}{|l|}{ Academic Qualification } \\
\hline LCE / SRP / PMR / MCE / SPM & 28 & 8.1 \\
\hline HSC / STPM / Certificate & 16 & 4.6 \\
\hline Diploma & 54 & 15.6 \\
\hline Bachelor Degree & 173 & 50.0 \\
\hline Master / PhD & 68 & 19.7 \\
\hline Others & 7 & 2.0 \\
\hline \multicolumn{3}{|l|}{ Marital Status } \\
\hline Married & 241 & 69.7 \\
\hline Single & 99 & 28.6 \\
\hline Others & 5 & 1.4 \\
\hline \multicolumn{3}{|l|}{ Vehicles Driving Experience } \\
\hline$<5$ years & 44 & 12.7 \\
\hline $5-10$ years & 78 & 22.5 \\
\hline $11-16$ years & 90 & 26.0 \\
\hline$>16$ years & 134 & 38.7 \\
\hline \multicolumn{3}{|l|}{ Occupation Categories } \\
\hline Private & 189 & 54.6 \\
\hline Government & 88 & 25.4 \\
\hline Retiree & 2 & 0.6 \\
\hline Self-Employed & 26 & 7.5 \\
\hline Student & 20 & 5.8 \\
\hline Others & 21 & 6.1 \\
\hline
\end{tabular}


Table 1: Demographic attributes of the respondents $(\mathrm{n}=346)$ (cont)

\begin{tabular}{lcc}
\hline \multicolumn{1}{c}{ Respondents' profile } & Frequency & Percentage (\%) \\
\hline $\begin{array}{l}\text { Monthly Income (RM) } \\
<3,000\end{array}$ & 73 & \\
$3,000-6,000$ & 139 & 21.1 \\
$6,001-9,000$ & 86 & 40.2 \\
$9,0001-12,000$ & 22 & 24.9 \\
$12,001-15,000$ & 7 & 6.4 \\
$>15,000$ & 15 & 2.0 \\
Current Locality & & 4.3 \\
Selangor & 209 & \\
FT (KLumpur / Putrajaya) & 99 & 60.4 \\
Others & 38 & 28.6 \\
\hline
\end{tabular}

Table 2: Descriptive Statistics \& Reliability Analysis

\begin{tabular}{ccccccc}
\hline Variables & $\begin{array}{c}\text { Number } \\
\text { of Items }\end{array}$ & Mean & SD & Skewness & $\begin{array}{c}\text { Inter-Items } \\
\text { Coefficients }\end{array}$ & Cronbach $\boldsymbol{\alpha}$ \\
\hline EC & 6 & 3.82 & 0.59 & -0.699 & 0.285 & 0.700 \\
CK & 3 & 3.78 & 0.67 & -0.115 & 0.526 & 0.769 \\
PB & 3 & 2.96 & 0.82 & +0.024 & 0.573 & 0.801 \\
IR & 3 & 3.82 & 0.77 & -0.370 & 0.451 & 0.713 \\
DG & 6 & 3.18 & 0.64 & +0.054 & 0.412 & 0.802 \\
INT & 6 & 3.45 & 0.69 & -0.143 & 0.529 & 0.871 \\
\hline
\end{tabular}

\subsection{Relationship Analysis}

Pearson correlation coefficient was performed to determine the strength and direction of the linear relationship between the factors and electric vehicle usage intention. Correlation of less than 0.20 is considered as slight correlation, $0.20-0.40$ is considered low, $0.40-0.70$ is a moderate correlation, $0.70-0.90$ is a high correlation and correlation of more than 0.9 is considered very high (Lean, Zailani, Ramayah and Fernando, 2009). In this study, it was found that Environmental Concern, Consumer Knowledge, Psychological Benefits and Demographics have moderate correlation with Usage Intention while Infrastructure Readiness is not significant towards Usage Intention (see Table 3). 
Table 3: Inter-correlations of the variables

\begin{tabular}{ccccccc}
\hline Factors & INT & EC & CK & PB & IR & DG \\
\hline INT & 1.000 & & & & & \\
EC & 0.400 & 1.000 & & & & \\
CK & 0.564 & 0.296 & 1.000 & & & \\
PB & 0.404 & 0.089 & 0.357 & 1.000 & & \\
IR & -0.050 & -0.064 & -0.005 & 0.047 & 1.000 & \\
DG & 0.463 & 0.133 & 0.289 & 0.423 & 0.025 & 1.000 \\
\hline
\end{tabular}

Note: Correlation is significant at $\mathrm{p}<0.01$.

\subsection{Hypothesis Testing}

Linear regression-stepwise technique was carried out to test the hypotheses that comprised the direct effects of Environmental Concern, Consumer Knowledge, Psychological Benefits and Demographics on Usage Intention. Table 4 reveals that Environmental Concern, Consumer Knowledge, Psychological Benefits and Demographics were found to have significant impacts on electric vehicle Usage Intention in Malaysia, which explained about $47.7 \%$ of the variability. This indicated a good outcome based on the nature of social science research.

Table 4: Measurement model results

\begin{tabular}{ccccccc}
\hline Constructs & $\begin{array}{c}\text { Unstandardized } \\
\text { Coefficients }\end{array}$ & $\begin{array}{c}\text { Standardized } \\
\text { Coefficient }\end{array}$ & t-value & P-value & VIF \\
\cline { 2 - 7 } & $\beta$ & SD Error & $\beta$ & & & \\
\hline Constant & -0.325 & 0.223 & - & 1.456 & 0.146 & - \\
EC & 0.284 & 0.048 & 0.244 & 5.967 & 0.000 & 1.101 \\
CK & 0.378 & 0.045 & 0.365 & 8.319 & 0.000 & 1.272 \\
PB & 0.116 & 0.037 & 0.139 & 3.106 & 0.002 & 1.316 \\
DG & 0.290 & 0.047 & 0.267 & 6.112 & 0.000 & 1.256 \\
\hline
\end{tabular}

Notes: $\mathrm{R}=0.695, \mathrm{R}^{2}=48.3 \%$, Adjusted $\mathrm{R}^{2}=47.7 \%, \mathrm{~F}=79.667$, Sig. $=0.00$

As the model is a cross-section containing five constructs, multicollinearity does not exist as the value of VIF test is less than 5. It was also revealed that the F-value is large enough to be accepted statistically and the corresponding p-value is highly significant at 0.00 or lower than 0.05 . This implied that all the four predictors have a significant impact on usage intention. In term of the predictors ranking, it is as follows: CK, DG, EC and PB. All the four domains support H1, H2, H3 and H5. The other predictor i.e. IR does not support H4, as it was not found to have a significant impact on INT (see Table 5). 
Table 5: Results of Hypothesis Testing

\begin{tabular}{ccccc}
\hline Hypotheses & $\begin{array}{c}\text { Hypotheses } \\
\text { Path }\end{array}$ & $\begin{array}{c}\text { Standardised Path } \\
\text { Coefficients }\end{array}$ & P-value & Result \\
\hline H1 & EC $\rightarrow$ INT & 0.244 & $0.000^{*}$ & Supported \\
H2 & CK $\rightarrow$ INT & 0.365 & $0.000^{*}$ & Supported \\
H3 & PB $\rightarrow$ INT & 0.139 & $0.002^{*}$ & Supported \\
H4 & IR $\rightarrow$ INT & NS & NS & Rejected \\
H5 & DG $\rightarrow$ INT & 0.267 & $0.000^{*}$ & Supported \\
\hline
\end{tabular}

Notes: ${ }^{*} \mathrm{p}$-value $<0.01 ; \mathrm{NS}=$ Not Significant.

The results of this study reveal that Environmental Concern, Consumer Knowledge, Psychological Benefits and Demographics are key predictors of electric vehicle Usage Intention in Malaysia. It also indicates the positive effects of Environmental Concern, Consumer Knowledge, Psychological Benefits and Demographics on electric vehicle Usage Intention. The research model expounded here holds promise for assisting other researchers and practitioners to develop understanding the key factors that influencing the electric vehicles usage intention in Malaysia.

It was also found that Infrastructure Readiness was not significant in this study. This is mainly due to the availability of the current technology of electric vehicle enabling user to charge their vehicle at home or at the workplace as long as an electricity plug for charging is available. As the key usage of electric vehicles is mainly for city and short distance use, charging was not the main issue in Malaysia as the travel distance per single charge is still within the urban mobility range. Most of the respondents foresee that a single charge will allow them to travel comfortably to work place for at least a few days before the next charging cycle. Majority of the respondents also prefer to charge in the evening after work till the next morning while the vehicle is not in used at home using the normal charging mode. Therefore, availability of the public charging infrastructure was not the main concern and therefore was not significant at this moment of time. However, we believe that the need for public charging infrastructure will only be imminent when the market penetration of electric vehicle has matured and when electric vehicle is used for medium and long-range commuting. Therefore, we propose to investigate the effect of this determinant again in the future and it should not be ruled out in totality in the prediction of electric vehicle adoption.

\section{POLICY IMPLICATION\& DIRECTION FOR FUTURE RESEARCH}

This study has shed some lights into how automotives marketers could formulate strategies to increase the sale of electric vehicle among Malaysian consumers with Environmental Concern, Consumer Knowledge, Psychological Benefits and Demographics emerging as the key predictors of usage intention. Policy makers should formulate appropriate policy and intervention strategies to encourage the growth of electric vehicle usage in Malaysia as part 
of the strategy to increase energy efficiency, to reduce emissions and to lessen the reliance on fossil fuel within the transportation sector. Public awareness and education on the issue of climate change, energy efficiency and carbon emission will definitely help to raise the consumer knowledge level. This in turn will impact the higher level of acceptance of green vehicles. As the sample collected in this study represents the real population of consumers in Malaysia, the findings may give empirically justified foundation for the parties concerned to embark and develop strategies to encourage the adoption of electric vehicles. The current research was conducted among 346 private passenger car drivers with valid license in Malaysia. Therefore, further research need to be done to confirm whether the findings of this study is consistent with that of other countries. The researchers suggested testing the study's predictions in crosscultural studies. Furthermore, there were only five external antecedents of intention that had been tested in this study. There are possibilities that some other valid external antecedents were left out in this study and future research should include more factors that might influence the acceptance of electric vehicle.

\section{CONCLUSION}

The outcome of this study contributes a better understanding in extending green technologies in the automotives sectors and examined the rationales for accepting or rejecting electric vehicle usage by the public. The model developed in this study was able to explain $47.7 \%$ of the variance in public intention to use electric vehicle in Malaysia. Appropriate interventions can be undertaken to expedite the growth of the usage of energy efficient vehicles to tackle the dependency on fossil fuel and to reduce the emissions within the automotive sector in Malaysia. This outcome may be used as a baseline for further research to validate and develop a better model to explain intention to use electric vehicles in Malaysia. It is hoped that this study gives a preliminary insight and perspective on the Malaysian consumer on the acceptance of electric vehicles.

\section{ACKNOWLEDGEMENT}

The authors would like to acknowledge the Institute of Energy and Policy Research (IEPRe), UNITEN for awarding the scholarship under the Energy Economics Chair endowed by Malaysian Electricity Supply Industries Trust Account (MESITA) for this research. Sincere appreciation is due to anonymous reviewers for valuable comments to improve this article. 


\section{REFERENCES}

Ajzen, I. (1991). The Theory of Planned Behavior. Organizational Behavior and Human Decision Processes, 50, 179-211.

Anegawa, T. (2010). Development of Quick Charging System for Electric Vehicle Development of Quick Charging System. Paper presented at the World Energy Congress. Canada: Montreal.

Balderjahn, I. (1988). Personality variables and environmental attitudes as predictors of ecologically responsible consumption patterns. Journal of Business Research, 17(1), $51-56$.

Bang, H. K., Ellinger, A. E., Hadjimarcou, J., \& Traichal, P. A. (2000). Consumer Concern, Knowledge, Belief and Attitude toward Renewable Energy: An Application of the Reasoned Action Theory. Psychology \& Marketing, 17(6), 449-468.

Bech-Larsen, T. (1996). Danish consumers' attitudes to the functional and environmental characteristics of food packaging. Journal of Consumer Policy, 19(3), 339-363.

Bekhet, H. A., \& Al-allak, B. A. M. (2011). Measuring Factors Affecting the Adoption of E-statement in Malaysia. Proceeding of 5th International Conference on Service Management, India (pp. 315-324).

Bekhet, H. A., \& Al-allak, B. A. M. (2014). Modelling client usage of e-statements: An empirical study in Malaysia. International Journal of Banking, Accounting and Finance, 5(3), 309-328.

Briggs, S. R., \& Cheek, J. M. (1986), The role of factor analysis in the development and evaluatbn of personality scales. Journal of Personality, 54, 106-148.

Brownstone, D., Bunch, D. S., \& Train, K. (2000). Joint mixed logit models of stated and revealed preferences for alternative-fuel vehicles. Transportation Research Part B, 34, $315-338$.

Chen, C. F., \& Chao, W. H. (2011). Habitual or reasoned? Using the theory of planned behaviour, technology acceptance model and habit to examine switching intentions towards public transit, Transportation Research Part F, 14, 128-137.

Cristea, M., Paran, F., \& Delhomme, P. (2013). Extending the theory of planned behavior: The role of behavioral options and additional factors in predicting speed behavior, Transportation Research Part F, 21, 122-132.

Dagsvik, J. K., Wennemo, T., Wetterwald, D. G., \& Aaberge, R. (2002). Potential demand for alternative fuel vehicles. Transportation Research Part B, 36, 361-384. 
Ellen, P. S. (1994). Do We Know What We Need to Know? Objective and Subjective Knowledge Effects on Pro-Ecological Behaviors. Journal of Business Research, 30, 43-52.

Ellen, P. S., Wiener, J. L., \& Cobb-Walgren, C. (1991). The role of perceived consumer effectiveness in motivating environmentally conscious behaviors. Journal of Public Policy and Marketing, 10(2), 102-117.

Energy Commission. (2014). National Energy Balance 2012. Putrajaya.

Ewing, G. O., \& Sarigollu, E. (1998). Car Fuel-Type Choice Under Travel Demand Management and Economic Incentives. Transportation Research Part D: Transport and Environment, 3(6), 429-444.

Garling, A., \& Thogersen, J. (2001). Marketing of electric vehicles. Business Strategy and the Environment, 10(1), 53-65.

Gould, J., \& Golob, T. F. (1998). Clean Air Forever? A Longitudinal Analysis of Opinions About Air Pollution and Electric Vehicles. Transportation Research Part D: Transport and Environment, 3(3), 157-169.

Gregan-Paxton, J., \& John, D. R. (1997). Consumer learning by analogy: A model of internal knowledge transfer. Journal of Consumer Research, 24, 266-284.

Griskevicius, V., Tybur, J. M., \& van den Bergh, B. (2010). Going green to be seen: status, reputation, and conspicuous conservation. Journal of Personality and Social Psychology, 98(3), 392-404.

Hansla, A., Gamble, A., Juliusson, A., \& Gärling, T. (2008). The relationships between awareness of consequences, environmental concern, and value orientations. Journal of Environmental Psychology, 28(1), 1-9.

Hartmann, P., \& Apaolaza-Ibáñez, V. (2012). Consumer attitude and purchase intention toward green energy brands: The roles of psychological benefits and environmental concern. Journal of Business Research, 65(9), 1254-1263.

Horvath, C., Lewis, I., \& Watson, B. (2012). Peer Passenger identity and passenger pressure on young drivers' speeding intentions, Transportation Research Part F, 15, 52-64.

Hsiao, C. H., \& Yang, C. (2010). Predicting the travel intention to take High Speed Rail among college students. Transportation Research Part F, 13, 277-287.

Kammerer, D. (2009). The effects of customer benefit and regulation on environmental product innovation. Ecological Economics, 68(8-9), 2285-2295. 
Lane, B., \& Potter, S. (2007). The adoption of cleaner vehicles in the UK: exploring the consumer attitude-action gap. Journal of Cleaner Production, 15(11-12), 1085-1092.

Laroche, M., Bergeron, J., \& Barbaro-Forleo, G. (2001). Targeting consumers who are willing to pay more for environmentally friendly products. Journal of Consumer Marketing, 18(6), 503-520.

Lean, O. K., Zailani, S., Ramayah, T., \& Fernando, Y. (2009). Factors influencing intention to use e-government services among citizens in Malaysia. International Journal of Information Management, 29(6), 458-475.

Lim, S., \& Lee, K. T. (2012). Implementation of biofuels in Malaysian transportation sector towards sustainable development: A case study of international cooperation between Malaysia and Japan. Renewable and Sustainable Energy Reviews, 16(4), 1790-1800.

Liu, J. (2012). Electric vehicle charging infrastructure assignment and power grid impacts assessment in Beijing. Energy Policy, 51, 544-557.

Lyons, E., \& Breakwell, G. M. (1994). Factors Predicting Environmental Concern and Indifference in 13- to 16-Year-Olds. Environment and Behavior, 26(2), 223-238.

Mahlia, T. M. I., Tohno, S., \& Tezuka, T. (2012). A review on fuel economy test procedure for automobiles: Implementation possibilities in Malaysia and lessons for other countries. Renewable and Sustainable Energy Reviews, 16(6), 4029-4046.

Mainieri, T., Barnett, E. G., Valdero, T. R., Unipan, J. B., \& Oskamp, S. (1997). Green Buying: The Influence of Environmental Concern on Consumer Behavior. The Journal of Social Psychology, 137(2), 189-204.

Martin, B., \& Simintiras, A. C. (1995). The impact of green product lines on the environment: does what they know affect how they feel? Marketing Intelligence \& Planning, 13(4), $16-23$.

Martin, E., Shaheen, S. A., Lipman, T. E., \& Lidicker, J. R. (2009). Behavioral response to hydrogen fuel cell vehicles and refueling: Results of California drive clinics. International Journal of Hydrogen Energy, 34(20), 8670-8680.

Martinsons, M. G., So, S. K. K., Tin, C., \& Wong, D. (1997). Hong Kong and China: Emerging Markets for Environmental Products and Technologies. Long Range Planning, 30(2), 277-290.

Mayor of London. (2009). An Electric Vehicle Delivery Plan for London. London, England, UK. 
Mills, B., \& Schleich, J. (2012). Residential energy-efficient technology adoption, energy conservation, knowledge, and attitudes: An analysis of European countries. Energy Policy, 49, 616-628.

Moan, I. S. (2013). Whether or not to ride with an intoxicated driver: predicting intentions using an extended version of the theory of planned bahaviour. Transportation Research Part F, 20, 193-205.

Mourato, S., Saynor, B., \& Hart, D. (2004). Greening London's black cabs: a study of driver's preferences for fuel cell taxis. Energy Policy, 32(5), 685-695.

Newell, S. J., \& Green, C. L. (1997). Racial Differences in Consumer Environmental Concern. Journal of Consumer Affairs, 31(1), 53-69.

O'Garra, T., Mourato, S., \& Pearson, P. (2005). Analysing awareness and acceptability of hydrogen vehicles: A London case study. International Journal of Hydrogen Energy, 30(6), 649-659.

Okamura, K., Fujita, G., Kihira, M., Kosuge, R., \& Mitsui, T. (2012). Predicting motivational determinants of seatbelt non-use in the front seat: a field study. Transportation Research Part F, 15, 502-513.

Pallant, J. (2011). SPSS Survival Manual, 4th Edition. Crows Nest, NSW: Allen \& Unwin, p. 359 .

Potoglou, D., \& Kanaroglou, P. S. (2007). Household demand and willingness to pay for clean vehicles. Transportation Research Part D: Transport and Environment, 12(4), 264-274.

Rivis, A., Abraham, C., \& Snook, S. (2011). Understanding young and old male drivers' willingness to drive while intoxicated: the predictive utility of constructs specified by the theory of planned behaviour and the prototype willingness model. British Journal of Health Psychology, 16, 445-456.

Road Transport Department. (2013). Motor Vehicles Statistics 2012. Putrajaya.

Roberts, J. A. (1996). Green Consumers in the 1990s : Profile and Implications for Advertising. Journal of Business Research, 36, 217-231.

Roberts, J. A., \& Bacon, D. R. (1997). Exploring the Subtle Relationships between Environmental Concern and Ecologically Conscious Consumer Behavior. Journal of Business Research, 40, 79-89.

Saaksjarvi, M. (2003). Consumer adoption of technological innovations. European Journal of Innovation Management, 6(2), 90-100. 
Saidur, R., Sattar, M. A., Masjuki, H. H., Ahmed, S., \& Hashim, U. (2007). An estimation of the energy and exergy efficiencies for the energy resources consumption in the transportation sector in Malaysia. Energy Policy, 35(8), 4018-4026.

Schafer, A. (2000). Regularities in travel demand: an international perspective. Journal of Transportation and Statistics, December, 1-31.

Schahn, J., \& Holzer, E. (1990). Studies of Individual Environmental Concern: The Role of Knowledge, Gender, and Background Variables. Environment and Behavior, 22(6), $767-$ 786.

Schroeder, A., \& Traber, T. (2012). The economics of fast charging infrastructure for electric vehicles. Energy Policy, 43, 136-144.

Schuitema, G., Anable, J., Skippon, S., \& Kinnear, N. (2013). The role of instrumental, hedonic and symbolic attributes in the intention to adopt electric vehicles. Transportation Research Part A: Policy and Practice, 48, 39-49.

Scott, S. (1997). Household energy efficiency in Ireland : A replication study of ownership of energy saving items. Energy Economics, 19, 187-208.

Shen, W., Han, W., Chock, D., Chai, Q., \& Zhang, A. (2012). Well-to-wheels life-cycle analysis of alternative fuels and vehicle technologies in China. Energy Policy, 49, 296-307.

Sheppard, B. H., Hartwick, J., \& Warshaw, P. R. (1988). The theory of reasoned action: A metaanalysis of past research with recommendations for modifications and future research. Journal of Consumer Research, 15, 309-324.

Simsekoglu, O., \& Lajunen, T. (2008). Social psychology of seat belt use: a comparison of theory of planned behaviour and health belief model, Transportation Research Part F, 11, 181-191.

Skerlos, S. J., \& Winebrake, J. J. (2010). Targeting plug-in hybrid electric vehicle policies to increase social benefits. Energy Policy, 38(2), 705-708.

Sperling, D., \& Kitamura, R. (1986). Refueling and New Fuels: An Exploratory Analysis. Transportation Research Part A, 20A(1), 15-23.

Sriram, V., \& Forman, A. M. (1993). The relative importance of products' environmental attributes : A cross-cultural comparison. International Marketing Review, 10(3), 51-70.

Thesen, G., \& Langhelle, O. (2008). Awareness, acceptability and attitudes towards hydrogen vehicles and filling stations: A Greater Stavanger case study and comparisons with London. International Journal of Hydrogen Energy, 33(21), 5859-5867. 
Ustaoğlu, M., \& Yıldız, B. (2012). Innovative Green Technology in Turkey: Electric Vehicles' Future and Forecasting Market Share. Procedia - Social and Behavioral Sciences, 41, 139-146.

Webster, F. V., Bly, P. H., Johnson, R. H., \& Dasgupta, M. (1986b). Part 2: Public transport and future patterns of travel. Transport Reviews, 6(2), 129-172.

Webster, F. V., Bly, P.H., Johnson, R. H., \& Dasgupta, M. (1986a). Part 1: Urbanization, household travel and car ownership. Transport Reviews, 6(1), 49-86.

Wustenhagen, R., \& Bilharz, M. (2006). Green energy market development in Germany: effective public policy and emerging customer demand. Energy Policy, 34(13), 16811696. 